\title{
Băģấfîmana Motivasi Berhenti Merokok Mahasiswa Di Kampus Kesehatan Yogyakarta?
}

Heni Trisnowati, Eka Santi Sabariah, Yelli Yani Rusyani

Pendahuluan

Masalah rokok sudah menjadi masalah nasional bahkan menjadi masalah internasional. Prevalensi merokok di Indonesia sangat tinggi di berbagai lapisan masyarakat, terutama pada laki-laki mulai dari anak-anak, remaja dan dewasa. ${ }^{(1)}$ Kecenderungan
merokok terus meningkat dari tahun ke tahun baik pada laki-laki dan perempuan (Gambar 1). Studi di Amerika menunjukkan prevalensi merokok mahasiswa cukup tinggi dan kelompok tertinggi pada usia 18-24 tahun ${ }^{(2)}$ Lebih dari 60 juta penduduk Indonesia mengalam ketidakberdayaan akibat dari adiksi nikotin rokok dan kematian akibat mengkonsumsi rokok tercatat lebih dar 400 ribu orang per-tahun. ${ }^{(3,4)}$. Mahasiswa sebagai calon tenaga profesional kesehatan tak luput dari kondisi tersebut. Sebagai salah satu upaya membantu perokok untuk berhenti merokok diperlukan informasi mengenai gambaran motivasi berhenti merokok

\section{Tujuan}

Penelitian ini bertujuan untuk mengetahui proporsi perokok pada responden penelitian dan untuk mengetahui gambaran motivasi berhenti merokok pada mahasiswa di kampus kesehatan Yogyakarta.

Gambar 1. Prevalensi Merokok Di Indonesia

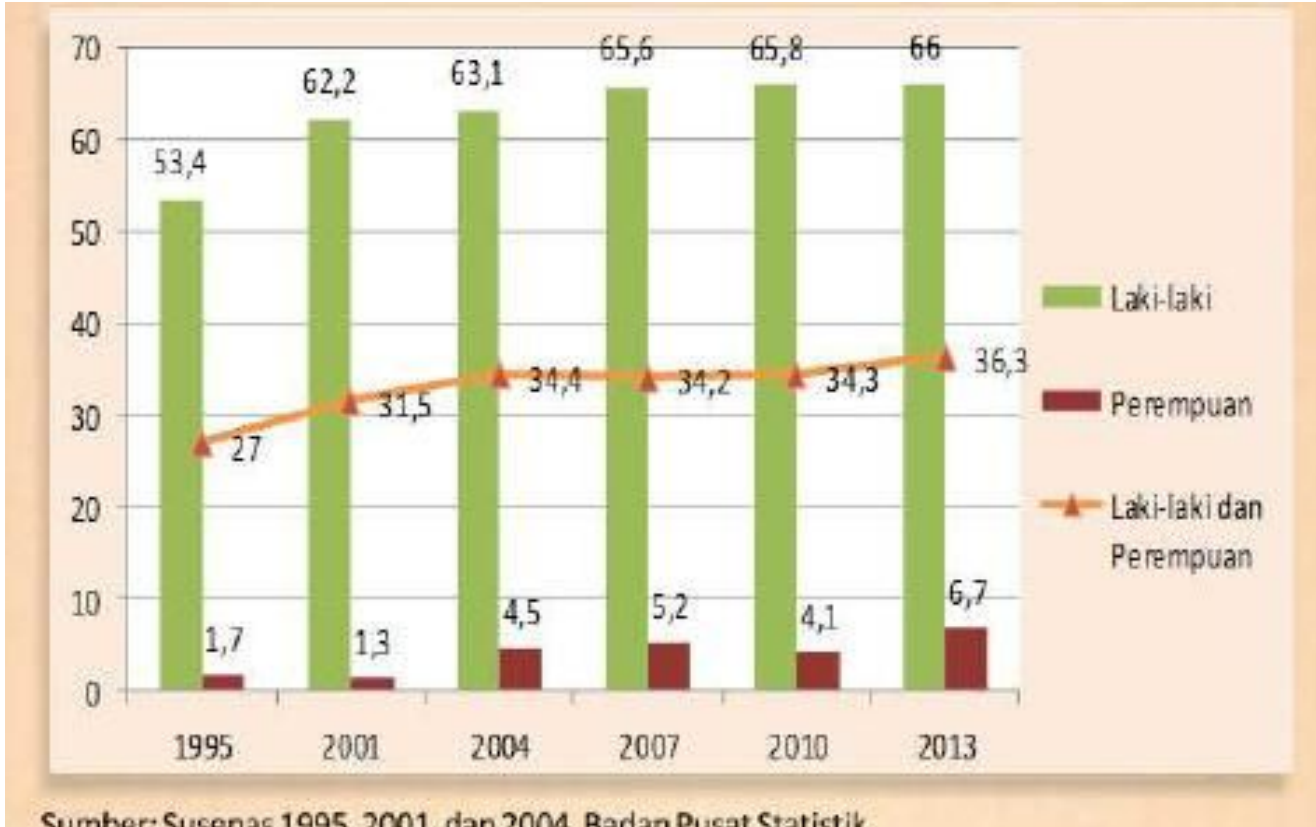

Sumber: Susenas 1995, 2001, dan 2004, Badan Pusat Statisti

\section{METODE}

Penelitian ini menggunakan metode kuantitatif dengan pendektan cross sectional.

Jumlah Populasi penelitian 274 orang sementara sample diambil dengan menggunakan accidental sampling

sebanyak 163 orang. berhenti merokok mahasiswa diperoleh dari kuesione kriptif menggunakan

Tabel 1. Karaktersitik Reponden Penelitian

\begin{tabular}{|c|c|c|}
\hline Karakteristik & Frekuensi & Persentase \% \\
\hline \multicolumn{3}{|l|}{ Perokok } \\
\hline $\begin{array}{l}\text { a. Laki-laki } \\
\text { b. Perempuan }\end{array}$ & $\frac{15}{5}$ & $\begin{array}{ll}75,0 \\
250\end{array}$ \\
\hline \multicolumn{3}{|l|}{ Non-perokok } \\
\hline c. Laki-laki & 31 & 21,8 \\
\hline d. Perempuan & 112 & 78.3 \\
\hline \multicolumn{3}{|c|}{ Jumlah rokok yang dihisap perhari dalam waktu $24 \mathrm{jam}$} \\
\hline a. $1-5$ batang & 7 & 35,0 \\
\hline b. $6-15$ batang & 5 & 25,0 \\
\hline c. $>15$ batang & 8 & 40,0 \\
\hline \multicolumn{3}{|c|}{ Menurut sejak kapan merokok } \\
\hline a. SD & 2 & 10.0 \\
\hline b. SMP & 5 & 25,0 \\
\hline c. SMA & 9 & 45,0 \\
\hline d. Kuliah & 1 & 5,0 \\
\hline e. Tidak Diketahui & 3 & 15,0 \\
\hline \multicolumn{3}{|l|}{ Menurut alasan merokok } \\
\hline a Lingkunga & 6 & \\
\hline $\begin{array}{l}\text { a. Lingkungan } \\
\text { b. Stress }\end{array}$ & 3 & 15,0 \\
\hline $\begin{array}{l}\text { c. Ketagihan keinginan } \\
\text { sendiri }\end{array}$ & 8 & 40,0 \\
\hline Tidak Dik & 3 & 15,0 \\
\hline
\end{tabular}

HASIL \& DISKUSI

Jumlah mahasiswa yang merokok sebanyak 20 orang $(12.3 \%)$ sementara proporsi perokok laki-laki 4 kali leb besar dibanding perokok wanita dan semua perokok mempunyai keinginan berhenti merokok.

Pada kelompok laki-laki, terdapat 15 orang (32.6\%) yang merokok sementara pada kelompok perempuan ada 5 orang $(4.3 \%)$ yang merokok.

Gambaran motivasi berhenti merokok sebagai berikut mahasiswa yang sangat tertarik untuk berhenti merokok sebanyak 12 orang $(60 \%)$
Gambar 3 : Proporsi Perilaku Merokok Responden Merokok Tidak merokok

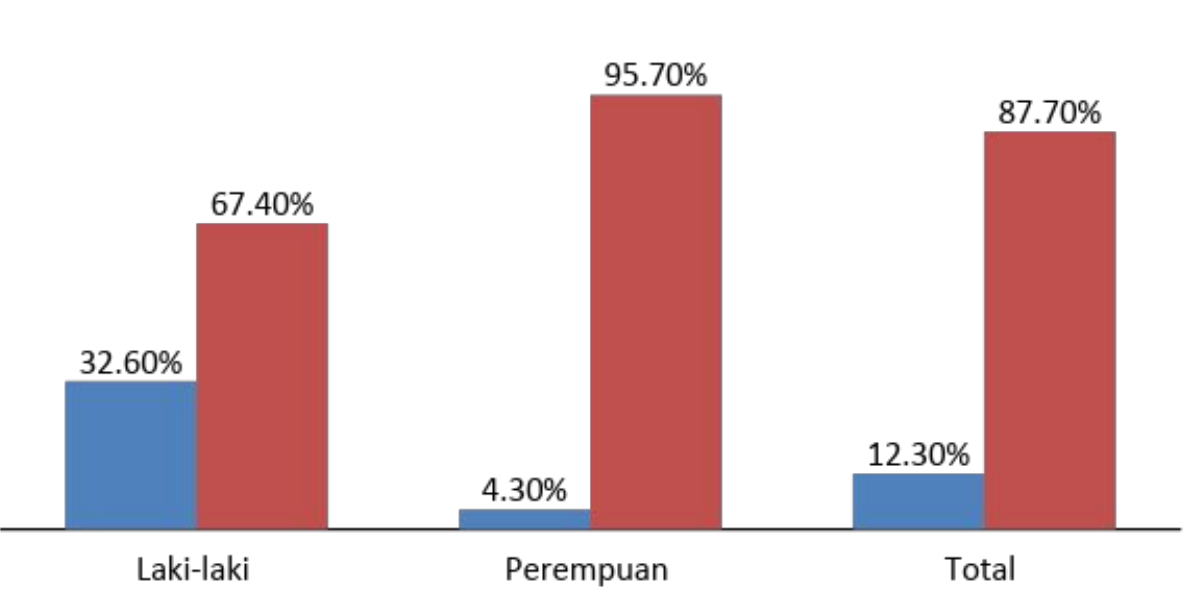

Jumlah mahasiswa yang akan berhenti merokok 7 orang (35\%) sementara ada 9 orang (45\%) kemungkinan akan menjadi non perokok. Sebagian besar $(65 \%)$ perokok
mempunyai motivasi sedang untuk berhenti merokok.

Seorang perokok yang memiliki motivasi tinggi akan cukup berhasil dalam prosesnya untuk berhenti merokok karena mempunyai dorongan yang kuat untuk bisa tidak merokok, sedangkan seorang peroko yang memiliki motivasi rendah dan cenderung tidak memili moleka akan biasanya dan akan mengalami kegagalan untuk berhent merokok (5)

Adapun yang membuat seseorang sulit berhenti merokok adalah nikotin karena bersifat adiktif sehingga membuat seorang perokok menjadi kecanduan secara fisik dan emosional. Apabila seorang perokok menghentikan kebiasaannya, ia pasti akan tersiksa, beberapara fisik maupun mentalnya. Walaupun begitu beran diantara mereka yang memiliki niat dan tekad siksaan candu ${ }^{(6)}$

Kunci utama keberhasilan program berhenti merokok adalah keinginan dan motivasi yang kuat dari perokok perokok berkeinginan untuk berhenti merokok ka secara sadar mereka sesungguhnya percaya akan resiko dan akibat buruk dari rokok dapat membahayakan diri mereka sendiri. Berhenti merokok merupakan suatu bentuk proses, yang dimulai dengan pembentukan niat dalam diri individu hingga mempertahankan masa bebas rokok secara jangka panjang
Gambar 3 : Motivasi Berhenti Merokok Responden

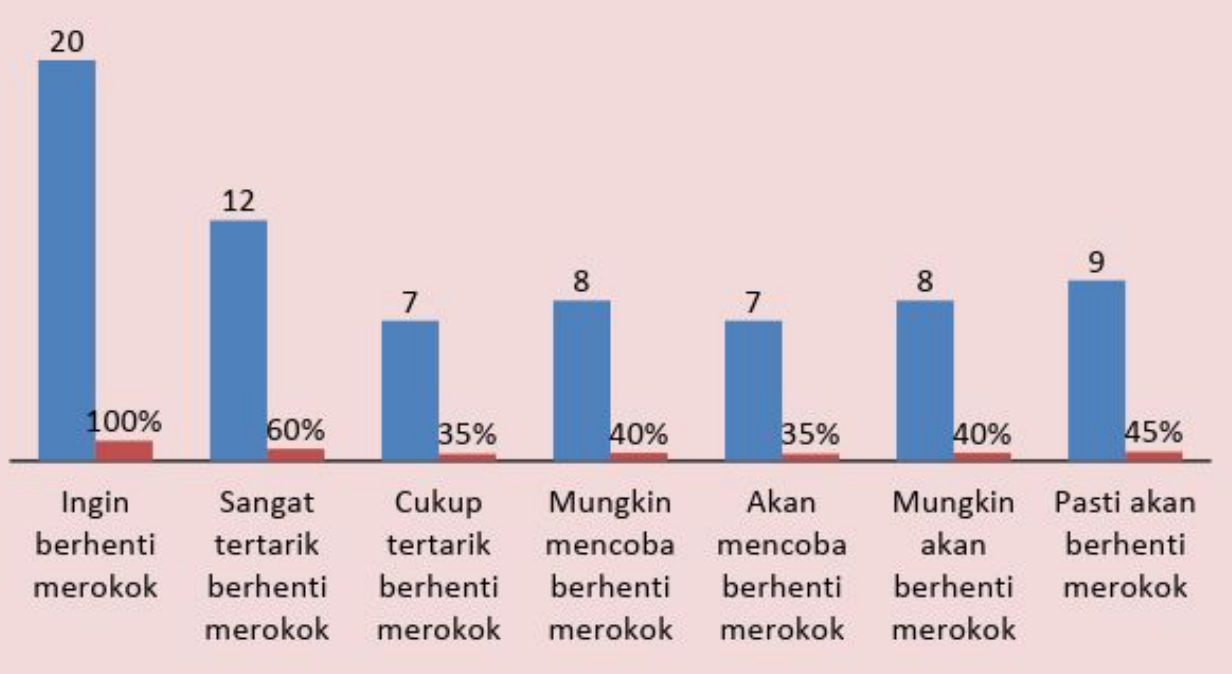

\section{Kesimpulan}

Semua responden yang merokok memiliki motivasi untuk berhenti merokok. Hal ini memberi peluang bagi promotor 作 perokek ber talam bentuk edukasi atau paran berhenti merokok.

Referensi

Nururrahmah (2014). Pengaruh Rokok Terhadap Kesehatan Dan Pembentukar (2015) Pust data dan informas Kesehatan
Kementerian Kesehatan Republik Indonesia (2007) Riset Kesehatan Dasar

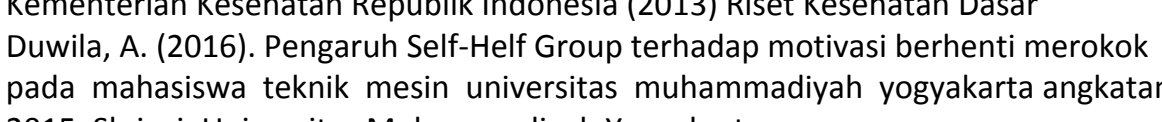
2015. Skripsi: Universitas Muhammadivah Yogyakarta

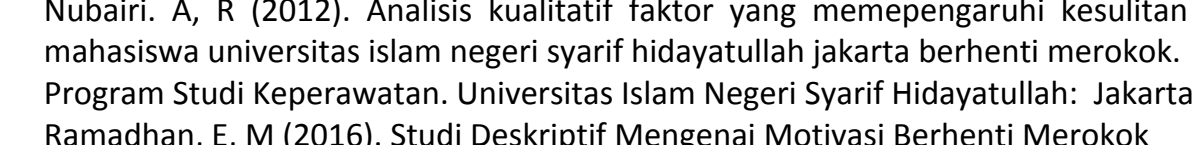

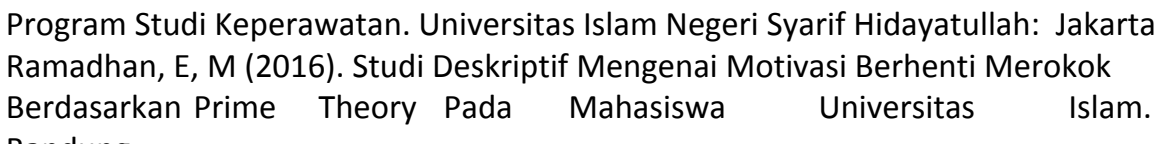

\section{ro 앙 Public Health \\ UUM Symposium

